University of Massachusetts Amherst ScholarWorks@UMass Amherst

Anthropology Department Faculty Publication

Series

Anthropology

January 1972

\title{
Town and countryside in Serbia in the nineteenth- century, social and household structure as reflected in the census of 1863
}

Joel Halpern

University of Massachusetts, Amherst, jmhalpern@anthro.umass.edu

Follow this and additional works at: https://scholarworks.umass.edu/anthro_faculty_pubs

Part of the Anthropology Commons

\section{Recommended Citation}

Halpern, Joel, "Town and countryside in Serbia in the nineteenth-century, social and household structure as reflected in the census of 1863" (1972). Household and Family in Past Time. 66.

https://scholarworks.umass.edu/anthro_faculty_pubs/66 


\section{Household and Family}

\section{in Past time}

Edited with an analytic introduction

on the history of the family

by Peter Laslett
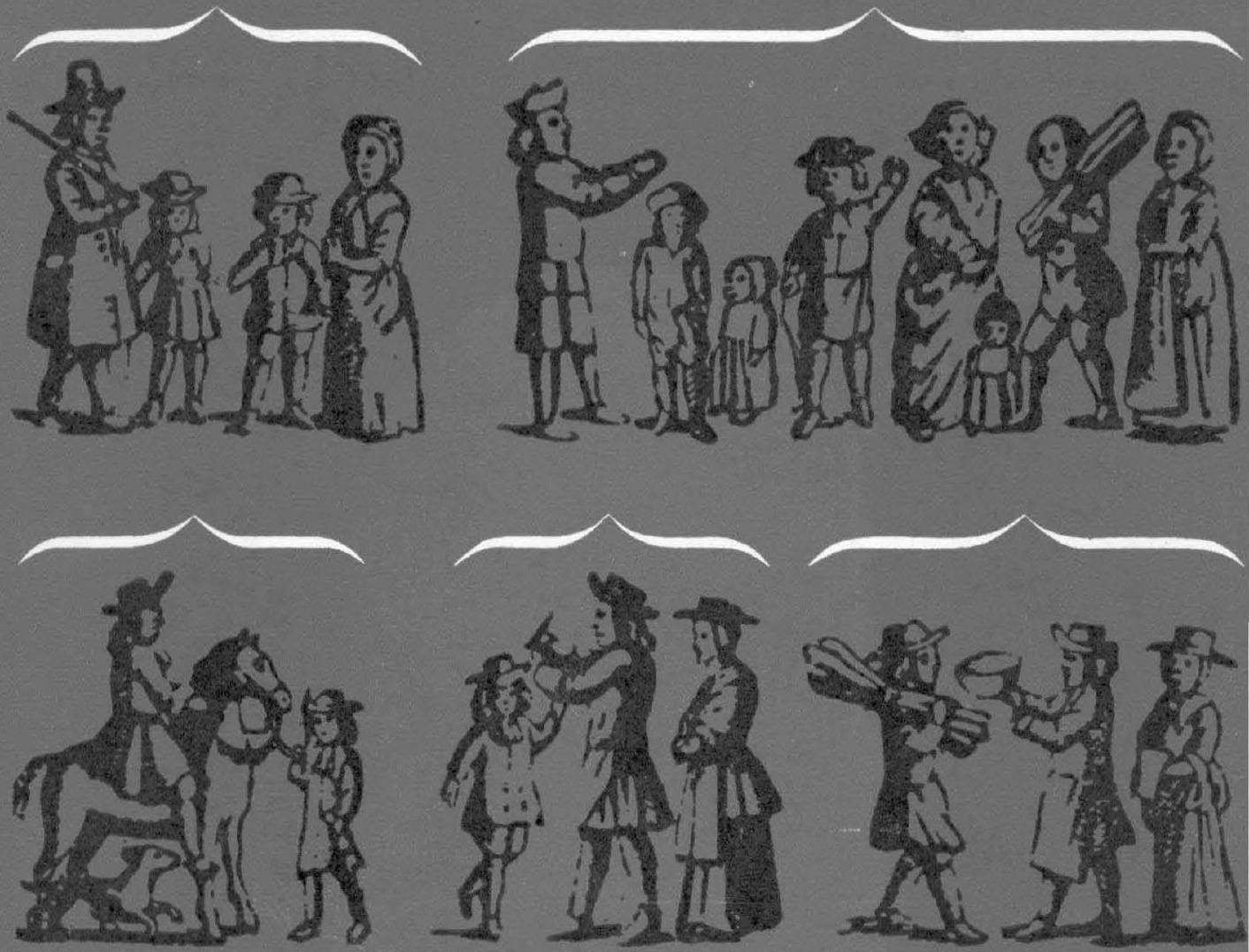

Cambridge University Press 


\section{Nineteenth-Century Society}

Essays in the Use of Quantitative Methods for the Study of Social Data

Edited by E. A. WRIGLEY

Of the Cambridge Group for the History of Population and Social Structure

This collection of nine essays demonstrates the opportunities offered by the accumulation of statistical information for studying nineteenth century society in depth, and discusses the associated difficulties.

The authors emphasize quantitative methods of analysis, and concentrate chiefly on the census. They discuss what information was required on census night, how the information was collected, how accurately and completely population characteristics were recorded, the problems which arise in attempting to use either the published census volumes or the enumerators' books, and the techniques which have proved useful in analysis. Related topics covered include the study of family structure, the use of information about occupation, the measurement of migration, criminal statistics, educational provision, and sampling in historical research.

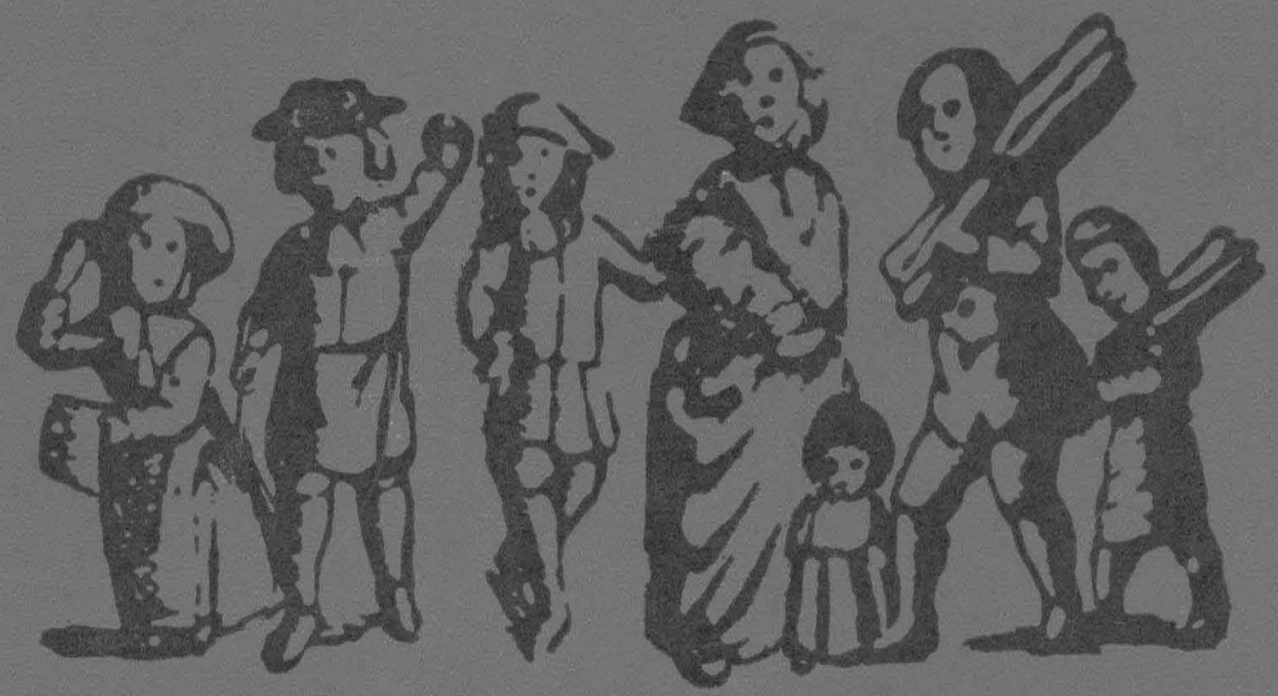


A Publication of the Cambridge Group

for the History of Population and Social Structure

Household and family in past time 


\section{Household and family in past time}

Comparative studies in the size and structure of the domestic group over the last three centuries in England, France, Serbia, Japan and colonial North America, with further materials from Western Europe

edited, with an analytic introduction on the history of the family, by PETER LASLETT

with the assistance of RICHARD WALL

both of the Cambridge Group for the History of Population and Social Structure 
Published by the Syndics of the Cambridge University Press Bentley House, 200 Euston Road, London NW1 2DB American Branch: 32 East 57th Street, New York, N.Y.10022

(C) Cambridge University Press 1972

Library of Congress Catalogue Card Number: 77-190420

ISBN: 0521084733

Printed in Great Britain

at the University Printing House, Cambridg

(Brooke Crutchley, University Printer)

This volume is dedicated to the memory of JAMES THORNTON, who died in 1969, Director of the London Branch of the Calouste Gulbenkian Foundation of Lisbon. The studies at Cambridge which gave rise to these published results for England were first supported by the Foundation when Mr Thornton was its Director. The international interchange at which many of the papers were read in September 1969 also took place under the Foundation's patronage. $\mathrm{Mr}$ Thornton showed a remarkable understanding of a new branch of learning in the process of coming into being.

\section{Contents}

List of contributors

page vii

Preface

ix

1 Introduction: The history of the family: Peter Laslett

I The history of the family

II Definitions, methods and scheme of analysis

III Numerical comparisons between five areas

IV Familial ideology and familial experience

Appendix: Suggested rules for interpreting English documents

2 Some demographic determinants of average household size: An analytic approach: Thomas K. Burch

3 The evolution of the family: Jack Goody

ENGLAND

4 Mean household size in England since the sixteenth century: Peter Laslett

5 Mean household size in England from printed sources: Richard Wall

6 A note on the household structure of mid-nineteenth-century York in comparative perspective: W. A. Armstrong

7 Household structure and the industrial revolution; midnineteenth-century Preston in comparative perspective: Michael Anderson

WESTERN EUROPE

8 A southern French village: the inhabitants of Montplaisant in 1644: Jean-Noël Biraben

9 Size and structure of households in a northern French village between 1836 and 1861: Yves Blayo

10 Household and family in Tuscany in 1427: Christiane Klapisch

11 Structure of household and family in Corsica, 1769-71: Jacques Dupâquier and Louis Jadin 
12 Variations in the size and structure of the household in the United Provinces of the Netherlands in the seventeenth and eighteenth centuries: A. M. van der Woude

13 Size of households before the industrial revolution: the case of Liège in 1801: Étienne Hélin

SERBIA

14 The zadruga as process: E. A. Hammel

15 Houseful and household in an eighteenth-century Balkan city. A tabular analysis of the listing of the Serbian sector of Belgrade in 1733-4: Peter Laslett and Marilyn Clarke

16 Town and countryside in Serbia in the nineteenth century, social and household structure as reflected in the census of 1863: Joel M. Halpern

JAPAN

17 Small families, small households, and residential instability: town and city in 'pre-modern' Japan: Robert J. Smith

18 Size of household in a Japanese county throughout the Tokugawa era: Akira Hayami and Nobuko Uchida

19 An interpretation of the size and structure of the household in Japan over three centuries: Chie Nakane

NORTH AMERICA

20 The average size of families and households in the Province of Massachusetts in 1764 and in the United States in 1790: an overview: Philip J. Greven, Jr

21 Demography and psychology in the historical study of family-life: a personal report: John Demos

22 Rhode Island family structure: 1875 and 1960 :

Edward T. Pryor, Jr

Bibliography

Index

\section{Contributors}

Anderson, Michael Lecturer in Sociology, University of Edinburgh Armstrong, W. A.

Senior Lecturer in History, University of Kent, Canterbury

Biraben, Jean-Noël Chargé de Missions, Institut National D’Études Démographiques, Paris

Blayo, Yves

Burch, Thomas K.

graphiques, Paris

Associate Director, Demographic Division, the Population Council, New York

Clarke, Marilyn

Research Assistant, Cambridge Group for the History of Population and Social Structure

Demos, John Associate Professor of History, Brandeis University, Waltham, Massachusetts, U.S.A.

Dupâquier, Jacques Directeur D'Études, École Pratique des Hautes Études, VIe Section, Paris

Goody, Jack

Professor-elect to the William Wyse Chair in Social Anthropology and Fellow of St John's College, University of Cambridge

Greven, Philip J. Jr Professor of History, Rutgers College, New Brunswick, New Jersey, U.S.A.

Halpern, Joel, M. Professor of Anthropology, University of Massachusetts, Amherst, U.S.A.

Hammel, E. A.

Hayami, Akira

Hélin, Étienne

Jadin, Louis

Klapisch, Christiane

Professor of Anthropology, University of California, Berkeley, U.S.A.

Professor of Economic History, Keio University, Tokyo, Japan

Professor of History, University of Liège, Belgium

Research Assistant, École Pratique des Hautes Études, VIe Section, Paris

Laslett, Peter

Nakane, Chie
Maître Assistant, École Pratique des Hautes Études, VIe Section, Paris

Reader in Politics and the History of Social Structure and Fellow of Trinity College, University of Cambridge

Professor of Anthropology, Institute of Oriental Culture, University of Tokyo, Japan 
Pryor, Edward T. Jr Chairman and Associate Professor, Department of Sociology, University of Western Ontario, London, Ontario, Canada

Smith, Robert J. Professor of Anthropology and Asian Studies, ViceChairman, Department of Anthropology, Cornell University, Ithaca, New York

Uchida, Nobuko Research Assistant, Faculty of Economics, Keio University, Tokyo, Japan

Wall, Richard Research Officer, Cambridge Group for the History of Population and Social Structure

van der Woude, A. M. Senior Lecturer, Department of Rural History, Agricultural University, Wageningen, The Netherlands 


\section{Town and countryside in Serbia in the nineteenth-century, social and household structure as reflected in the census of $1863^{1}$}

\section{Joel M. Halpern}

Balkan familial and household structure has been the subject of discussion and study for over a century, but not much attention has been paid to the specifics of size and kinship composition. If we give as a brief tentative definition of the zadruga an extended household composed of a father and his married sons and their offspring (paternal zadruga), or two or more married brothers and their children (fraternal zadruga), how many people in a given community actually lived in these types of households? What about the size of the households themselves? Much of the literature with respect to the zadruga seems to dwell on the exceptional case which is then described in detail. Such an approach, however, does not help us understand the conditions under which the majority of the people lived. In this chapter an attempt will be made to establish in a preliminary way specific data bearing on household size and composition as it existed in the nineteenth century in certain villages in central Šumadija in Serbia (Orašac, Banja, Bukovik, Kopljare, Stojnik and Topola) and one emergent market town (Arandjelovac).

A glance at Tables $16.1 a-h$ establishes that with the notable exception of the market town the large majority of households contain six or more people according to the 1863 Census. ${ }^{2}$ Arandjelovac has approximately $20 \%$ of its people listed as living alone (see below, Table 16.1a), although this may be in part an artifact of the Census since many of these were probably boarders in other

${ }^{1}$ The research on which this paper is based was supported by grants from the National Science Foundation and the National Institute of Mental Health. Appreciation is also acknowledged for assistance provided by the Archives of the Republic of Serbia, permitting access to census records, to personnel at the Serbian Archives who aided in the transcription of data, and to the University of Massachusetts Faculty Research Committee. A related paper, drawing exclusively on Orašac, one of the villages cited here, is Halpern, The zadruga, a century of change (1970).

${ }^{2}$ Despite the differences in the structure of households, it is noticeable that in the towns of Western Europe smaller households occurred more frequently than in the surrounding countryside. See above, van der Woude, Chapter 12, pp. 308-309; Hélin, Chapter 13, pp. 332-333. Compare the survey by Klapisch of fifteenth-century Tuscany, see above, Chapter 10, p. 275. 
households. Still, it is clear that these merchants and craftsmen were either young men beginning their careers or older men temporarily or permanently detached from their families. From what we know of contemporary rural-urban kin relationships in Serbia it is reasonable to suppose that many of these single people were migrants from surrounding villages, and they probably returned to their home villages fairly regularly. It would seem highly unlikely that they were without important kin ties in the surrounding area. It is also probable that few if any of these single individuals were born in the town. Of course, the whole idea of town or urban center must be used in a very restricted occupational sense, since we are here talking about a settlement of only 566 people.

If we use as our focus of interest the population at large rather than the household structure as such, we can see clearly that again, with the striking exception of Arandjelovac, the majority of the population lived in households size 6 or over, ranging from as high as $89 \%$ in the case of Orašac, to a minimum of $69 \%$ in Bukovik (the settlement adjoining Arandjelovac, and also containing commercial establishments).

If we compare the 1863 data with information available for the same villages for 1890 (Table 16.2) we see that with the exception of the town there have been no dramatic changes. The major change in Arandjelovac is the very sharp decline in households of size 1 . This may be in part a characteristic of the way in which the 1863 Census was carried out, or it may be explained by the growth of Arandjelovac as a trading center, so that by 1890 the merchants and craftsmen were more established with families. It is also possible that the decline in single person households in Banja, Bukovik and Stojnik may be explained by the greater accuracy of the later Census. Most important, however, is that the predominance of size 6-10 households continues to include approximately half the number of households and more than half the population in most cases. It also seems significant that, with the exception of Stojnik and Banja and the special case of Arandjelovac, the other villages in this survey show some decline in the relative proportions of households of size 11 and over. This is balanced by some increase in the size 4-5 category in most cases. Broadly viewed when compared to changes which were to occur in the twentieth century, the nineteenth century seems to have been a period of relative stability in household size. If we take all data into account, however, there does seem to have been a steady decline in average household size. In Orašac, for example, there was a decline of 1.4 , from a high of 8.3 in 1844 (the first records) to 6.9 in 1890. (In the much shorter period 1910-58, the decline was 2.1 , from 6.6 to 4.5 .)

However, once we get outside the Serbian culture area a different situation seems to prevail. In considering the case of village areas of the Republic of Dubrovnik for the end of the seventeenth century the differences are dramatic, with only approximately half of the population living in size 6 and larger households (Table 16.3). Interestingly, figures from Dubrovnik are slightly lower than those for the English village of Ealing at the end of the sixteenth century but much closer to the English than the Serbian situation. ${ }^{3}$

This point is further emphasized when compared to other European data. In Belgrade in $173380 \%$ of all persons were living in housefuls ${ }^{4}$ of 6 and above, but this figure is rivalled by three of the villages in our sample (Banja $79 \%$, Kopljare $83 \%$ and Orašac $89 \%$; these are all households, not housefuls), as Tables $16.1 a-h$ show. The mean size for the Serbian villages, taking the household as point of reference, range from 5.5 for Bukovik to 8.3 for Orašac, with the Belgrade data falling within this range. It is too early in this type of research to say that the Serbian data is unique, but from a European point of view it does contrast noticeably with the data from England. ${ }^{5}$

It is possible to set some limits on the frequency of large-size households in nineteenth-century Serbia. The evidence is clear from Tables $16.1 a-h$ that households of size 20 and over were rare. Specifically, they occur in only two of the villages, and there is one case from Belgrade. What do some of these large households look like in terms of kin structure? We can take as an example the 22-member Janko Nedić zadruga of Orašac. Here there is a combination of paternal and fraternal zadruga structure. Unfortunately since all kin are listed in relationship to the head of household we cannot determine the precise pairing of sons with wives and children. Generally, specific daughters-in-law can be linked to sons by age similarities. A further confusion is that although there are Slav words for daughter-in-law (nevjesta or mlada, for example), the SerboCroatian term snaha means both daughter-in-law and sister-in-law, thereby combining them in one category, but daughters-in-law are generally listed first, matching the preferential listing given sons over brothers.

Much more common are the households with 10 or more members, i.e. those of approximately half the size of the Nedić household. In Orašac almost half of all households were of size 10 or over $(48 \%$, ) and of these the most numerous were those of sizes 10 and 12 . Tables $16.1 a-h$ show that there were only one or two households in each category above size 13, representing in most cases no more than one or two percent of the total population in each category. Further, if we consider size 13 and over as a percent of the total population, only $9 \%$ in Bukovik, $17 \%$ in Kopljare and $19 \%$ in Orašac belonged to such households. Although these figures are not insignificant as compared with pre-industrial England for example, where only $1 \%$ of persons lived in such domestic groups, it is clear that most people in these Serbian villages of the 1860 s spent at least part of their lives in smaller-size households.

Further examples from Orašac in 1863 of a size 10, a size 8 and a size 6 house-

${ }_{4}^{3}$ For Ealing see above, Laslett, Chapter 1, Table 1.7, p. 77.

${ }^{4}$ See above Laslett and Clarke, Chapter 15. The authors distinguish between a household which is a kinship-family unit and the houseful which includes all the inhabitants of a particular house, including lodgers. For an exact definition of these terms see above, Laslett, Chapter 1 pp. 34-40. See also Hammel, Chapter 14, p. 339, footnote 13.

See above, Laslett, Chapter 4, pp. 130-131, 135-143; Wall, Chapter 5, pp. 174-190. 
hold give us a better idea of the kinds of family structure within which most people passed their lives. In Orašac approximately $52 \%$ of the population is found in size 6 to 10 households inclusive, and for all settlements the percentage is about 50. The size 10 household of Milosav Nedić may be taken as an illustra. tion: it had two married brothers, aged thirty and twenty-seven, with their wives, one and two years younger respectively. The head of the household had 3 small daughters. Three nieces were also listed, aged fifteen, twelve and seven, though only one of these could have been the child of the younger brother, given the customary age at marriage; they were more likely to have been the orphans of an older deceased brother. ${ }^{6}$

The issue of the adoption of a deceased brother's children and his wife is not without interest in connection with this particular household in Orašac in 1863, since the death of parents in the primary family formation years of twenty-one to forty was much greater in the nineteenth century than it is today. The relative proportion of all deaths in this age group for the period $1881-2$ was $15 \%$, while in 1951-2 it was only $3.8 \%{ }^{7}$ Although scattered death records for Orašac do exist for the 1860 s their incompleteness makes comparison with later years unsatisfactory, but it is reasonable to assume that if the comparison were made for the 1860s and the 1960s the contrast would be even greater.

Unlike the size 22 household, which has a maximal combination of married brothers with their children, plus the married sons of the oldest brother and their offspring, the 10-member household of Milosav Nedić was a zadruga of brothers in the process of formation. Obviously at ages thirty and twenty-seven neither brother was likely to have completed the formation of a family in terms of the number of children each young wife might bear.

A size 8 household in Orašac headed by Milan Jovanović, fifty, with a fortyyear-old wife and two married sons, aged twenty-five and twenty-three respectively, the two daughters-in-law and two children, gives an example of a paternal zadruga in the process of formation; the daughters-in-law are in an even earlier stage of producing children than are the young couples in the household previously cited. We may finally look at a household of 6 headed by Nikola Pavlović, forty, which included his forty-year-old wife and their 4 children ranging in age from twelve to three. Here the head of the household either had no brother or did not have one he chose to remain with in a zadruga. At the same time, his eldest child had not reached marriageable age.

In households of size 6 and below, the classic nuclear family is most frequent, comprising about a third (31\%) of all households. However, if the nuclear family

${ }^{6}$ It is not difficult to imagine the problems eventually faced by this randomly selected household, with six young girls to marry off in the overwhelmingly patriarchal and patriloca village society of that time. The total holdings of the household were 10 hectares, roughly the same amount as the previously cited zadruga of 22 persons. Therefore it would b reasonable to suppose that this size holding did attract at least one in-marrying male.

Halpern, Social and cultural change (1956) Table 13: 121, based on the records of the Orašac Village Council. is taken as a unit, its formation is not necessarily a simple matter to analyse. For example, in the case of Stevan Lukić, thirty, his wife, twenty-two, his son, two, and daughter, five, judging by the difference in age of husband and wife and by the age of the daughter, there is a possibility that the daughter was borne by former wife, possibly one who had died in childbirth. We also find a case where a boy of seventeen is listed as the household head living with his brothers aged thirteen, eleven and nine. It is possible that this group occupied a separate house, but received help from neighboring kin. ${ }^{8}$ Certainly if there had been fewer brothers, or if they had had more land than the 2.3 hectares due them, they might have been brought up in a paternal uncle's household, if such existed. There were also small nuclear families in Orašac just beginning to make their way, as in the case of Srećko Rajćić, twenty-two, his wife Andjelija twenty-five, and their infant son.

Household size as evidenced by these examples is, of course, something that exists only at one point in time. It is constantly changing, through the birth of new members or the death of the old and also of the young. It is further affected by influences connected with economy of size, by personality conflict and by various other factors such as government or tax regulations, which might cause brothers and their families to split off from each other, or sons to separate from fathers. Although households go through cycles as their members mature, if the sample is large enough, as in a village of a hundred or more households, it is reasonable to find households in various stages of formation as we have seen above. ${ }^{9}$

The obvious economic influence affecting household stability was the size of the land holding. With a large labor force it was possible for the zadruga to save money and purchase land, so that to some extent in the relatively egalitarian peasant economy, a large unit could prosper if well organized, even if it had started out with a small initial holding. In 1863 holdings ranged from a little over one hectare to as much as 14 hectares, but generally there was a fair correlation between the size of the holding and the size of the household. A family of 15 lived on the largest holding in 1863, while the largest household of 22 members had about 11 hectares. Of course, the important variable here was the number of able-bodied males rather than the total number of people in the household.

These statistics seem to me to show that the right combination of several married males together in one household, each with a relatively complete nuclear family, occurred in only a minority of cases.

Compare Dupâquier's statements about households of orphaned children remaining as independent units in Corsica in the 1770s, above, Chapter 11, pp. 292, 294. In England such children would usually be taken in by relatives, possibly with some help from the parish;

see above, Anderson, Chapter 7 , pp. $227-228$.
${ }^{9}$ For an example of the evolution of an individual through eight household formations in the For an example of the evolution of an individual through eight household formations in the
course of seventy years, see Joel and Barbara Halpern, A Serbian village in historical perspective (1972). See also above, Hammel, Chapter 14, pp. 370-373. 
Tables 16.4a- $f$ analyze the distribution of children in Arandjelovac and five of the villages. If children are defined as those eighteen years of age and under, between $60 \%$ and $71 \%$ were children of the head of the household, and $4 \%$ to $15 \%$ were his grandchildren. Offspring of other household members, primarily brothers of the household head, amounted to $20 \%$ to $29 \%$. This contrasts with Ealing where $89 \%$ of the children were children of the household head. ${ }^{10}$ Despite the relatively large number of grandchildren and nieces and nephews, the nuclear family was the basic structural component of the extended family household structure in Serbia.

This is further amplified by Tables $16.5 a-p$ where breakdowns are given according to selected kin categories. Characteristic of the most important kin links tying together the Serbian extended family structure in the nineteenth century was the relationship of the head of the household to one or more sons. If we compare Tables $16.5 a$ and $16.5 b$ and $16.5 e$ and $16.5 f$, we see that the number of sons exceeds the number of household heads in every village. The number of daughters also exceeds the number of household heads, though not by such a wide margin. For the five villages we get a ratio of 1.5 sons for every household head, ${ }^{11}$ and if daughters are included the ratio rises to 2.6 . On this basis, taking households headed by married persons only, including heads' wives but excluding other relatives, we get a mean household size of 4.6. Since the mean size of the household for all villages is 6.7 , approximately $70 \%$ of household composition can be attributed to nuclear family relationships. Put another way, using Orašac as an example, in 1863 out of 1,082 inhabitants, 703 were either household head, wife, son or daughter (calculating relationships with respect to the household head). Married coresident sons have been included in the nuclear families of their fathers. (Arandjelovac is excluded from the above calculations and those that follow.)

We can also take as a point of departure the population of children (under eighteen and unmarried). Tables $16.4 a-f$ demonstrate that children composed from $52 \%$ to $58 \%$ of the population in the Serbian villages of 1863 , whereas in Arandjelovac in that year, Belgrade in $1733^{12}$ and Ealing in $1599^{13}$ children were approximately one-third $(31 \%$ to $37 \%$ ) of the total population. As we have seen, about two-thirds of the children were the offspring of the head of the household, and between one-fifth and a quarter were the offspring of brothers of the household head, with the remaining numbers (reaching as high as $15 \%$ in Orašac) constituting grandchildren of the household head. It should be noted that there are very few four-generation households. These data reaffirm again the importance of the nuclear family core within the extended family household.

${ }_{10}$ Taken from the files of the Cambridge Group. It must be remembered, however, that these figures are for all children (all children present in the households), not simply those under

eighteen.
11 Compare Hammel's analysis of the Serbian Census of 1528, above, Chapter 14, pp. 361-362.

${ }_{12}$ See above, Laslett and Clarke, Chapter 15, pp. 379-380, 385.

${ }_{13}$ Taken from the files of the Cambridge Group.
It may be noticed, however, that the head of the household and his wife were not necessarily a part of this nuclear core. This would seem to be true in about a quarter of the households, when the eldest son had reached an age to found his own family. This occurred generally when the household head and his wife were in their forties (see Tables $16.5 a-d$ ).

A good way to follow the cycle of extended household formation, reformulation and division is to focus on nuclear family formation within the extended kin unit. As a son married and produced children, so the date of death of the parents approached. In the circumstances of 1863 in Serbia, the major factor affecting change was the death of the father, although division occasionally occurred before his death. Viewed from another perspective, if there were two married brothers together in a zadruga, they were most likely to divide as their children matured. We can see this by contrasting the age of brothers (Table 16.5j) and of household heads (Table 16.5b); about a quarter of the household heads were over forty but only some $5 \%$ of the brothers were in this category.

If we take households of size 10 and above, we can see that the son ratio rises to 2.5 , and the overall ratio of siblings to the household head rises to 4.3 . It can simply be stated that households were large in part because of the number of children of the household head. However, these figures and those cited in the preceding paragraphs take no account of the matter of married sons. The relatively larger proportion of mature sons in households of size 10 and above is reflected in the fact that most daughters-in-law are in the larger households (from one-third to three-quarters; see Tables $16.5 o$ and $16.5 p$ ). If the small sample of six in Bukovik is disregarded because of the small percentage of sons in the over-twenty age group, then we see that the lowest percentage is $52 \%{ }^{14}$

Viewed in terms of one specific village, Orašac, $32 \%$ of the households are in the 10-plus category (Table 16.1e), but these households contain $40 \%$ of the sons (Table 16.5e), $60 \%$ of the daughters-in-law (Table 16.50 ), $37 \%$ of the daughters (Table $16.5 \mathrm{~g}$ ), $59 \%$ of the brothers (Table $16.5 \mathrm{i}$ ), $93 \%$ of the nephews (Table $16.5 \mathrm{~m}$ ), and $80 \%$ of the grandsons (Table $16.5 \mathrm{k}$ ). However, in terms of total population households of over 10 persons contain only $49 \%$ of the population.

If what might be called the key non-nuclear family kin are taken into account, that is daughters-in-law and grandsons, we can see that for Topola and Banja, where $30 \%$ and $37 \%$ of the population are in households of size 10 and above, $52 \%$ and $73 \%$ of the daughters-in-law and $63 \%$ and $54 \%$ of the grandsons are in this category. In these same villages $46 \%$ of the Topola population lives in size 1-7 households and $44 \%$ in Banja. Households of these sizes include, respectively, $47 \%$ and $42 \%$ of the sons, $22 \%$ and $10 \%$ of the daughters-inlaw, and $8 \%$ and $15 \%$ of the grandsons. In the case of nephews the percentages for these categories are $13 \%$ and $15 \%$.

${ }^{14}$ Bukovik seems to share a number of characteristics with Arandjelovac, including small average household size and younger age of household head (see Table 16.5b). 


\section{J. M. HALPERN}

This preliminary analysis does not attempt any comprehensive survey of the social structure of households in nineteenth-century rural Serbia. What it seeks to emphasize is that the complex kin relationships which characterized the zadruga were ordinarily participated in at any one time by less than half of the population.

This statement applies not only to non-nuclear kin relationships, such as grandparent-grandchild, father-in-law-daughter-in-law and uncle-nephew, but partly also to those occasioned by multiple siblings, e.g. older brother-younger brother, older sister-younger brother. Much has been written elsewhere about the relationship between a daughter-in-law and a mother-in-law and between daughters-in-law in the same household. Obviously these are the people experiencing the full pattern of kin relationships occurring when the family cycle follows the classic pattern. But what of those families where there was only one son or where parents or siblings died young? What of the household whose limited land holding could support only a restricted number of members? Are these cases not as important as the 'ideal' ones, which can have been experienced by only a minority?

The fraternal and paternal zadrugas or combinations of these have attracted the interest of scholars. Investigations indicate that villagers of high status tended to come from larger, more complex households, which were in a better position to enlarge their holding precisely because of their superior manpower. During the nineteenth century, as the land began to fill up in central Serbia, economic and social competition intensified in the villages, since there was no large-scale outlet through emigration to towns. The ideal of several married sons joining together with their father or, after his death, several brothers and their families continuing to live in a joint household, persisted in a remarkable way. But we may well ask whether the significant proportion of people who lived in nuclear households (one-third) and households of size 5 and under (approximately a half) were in a generally deprived state? The question can be asked with respect to their standard of living, and with regard to their experiencing an emotional environment similar to that of the larger households. Given the realities of the family cycle, many individuals in the course of their lifetimes probably lived in both nuclear and extended family environments.

Scholars concerned with social structure have tended to concentrate on the fully complex, ideal patterns and neglected the smaller nuclear and fragmented households. We will not achieve a full picture of social life in the nineteenthcentury Serbian household unless we look at the smaller households as intensively as we have looked at the larger ones.

\section{Appendix ${ }^{a}$}

Tables 16.1 to 16.3 Detailed size of households, 1863 by settlements ${ }^{b}$ Two measures each for mean and median size of household, are used. The first (A) states that on the average the household has $\mathrm{X}$ people according to the formula

$$
\epsilon \frac{\text { si } \times \text { hsi }}{\text { no. of households }}
$$

that is, the size of the household(s) times the number of households in that size category (i), indicating all the different categories taken sequentially, and $\epsilon$ representing their sum total, e.g. for Arandjelovac (see Table 16.1a)

$$
\frac{1 \times 94+2 \times 27+3 \times 39 \ldots}{221}
$$

The second measure (B) indicates that on the average an individual lives in a household with $\mathrm{X}$ people according to the formula

$$
\epsilon \frac{\mathrm{si} \times \mathrm{psi}}{\text { no. of people in village }}
$$

e.g. the sum total of the size of the household times the number of people in that size category: for Arandjelovac this would be represented by

$$
\frac{1 \times 94+2 \times 54+3 \times 117}{566} \cdots
$$

\begin{tabular}{|c|c|c|c|c|}
\hline \multirow[b]{2}{*}{ Size } & \multicolumn{2}{|c|}{ Households } & \multicolumn{2}{|c|}{ Persons } \\
\hline & No. & $\%$ & No. & $\%$ \\
\hline 1 & 94 & 42.53 & 94 & 16.60 \\
\hline 2 & 27 & 12.21 & 54 & 9.54 \\
\hline 3 & 39 & 17.64 & 117 & 20.67 \\
\hline 4 & 29 & 13.12 & 116 & 20.49 \\
\hline 5 & 20 & 9.04 & 100 & 17.66 \\
\hline 6 & 6 & 2.71 & 36 & 6.36 \\
\hline 7 & 3 & 1.35 & 21 & 3.71 \\
\hline 8 & 1 & 0.45 & 8 & 1.41 \\
\hline 9 & - & - & - & - \\
\hline 10 & 2 & 0.90 & 20 & 3.53 \\
\hline Total & 221 & 100 & 566 & 100 \\
\hline \multicolumn{3}{|c|}{ Mean size of household } & \multicolumn{2}{|c|}{ Median no. of persons } \\
\hline \multicolumn{3}{|c|}{$\begin{array}{l}\mathrm{A}=2.6 \\
\mathrm{~B}=3.8\end{array}$} & \multicolumn{2}{|c|}{$\begin{aligned} A & =2 \\
B & =4\end{aligned}$} \\
\hline
\end{tabular}

The second measure is higher because it takes the individual rather than the household as the point of departure, and this is reflected in the mean as well.

Table 16.1a Arandjelovac

${ }^{a}$ The structure of Tables 16.1 to 16.4 follows that established by the Cambridge Group for the History of Population and Social Structure.

Arandjelovac, Banja, Bukovik, Kopljare, Orašac, Stojnik, and Topola (plus comparative data from Dubrovnik, 1673-4). 
Table $16.1 b$ Banja

\begin{tabular}{|c|c|c|c|c|}
\hline \multirow[b]{2}{*}{ Size } & \multicolumn{2}{|c|}{ Households } & \multicolumn{2}{|c|}{ Persons } \\
\hline & No. & $\%$ & No. & $\%$ \\
\hline 1 & 24 & 12.79 & 24 & 2.07 \\
\hline 2 & 11 & 5.94 & 22 & 1.89 \\
\hline 3 & 19 & 10.27 & 57 & 4.91 \\
\hline 4 & 11 & 5.94 & 44 & 3.79 \\
\hline 5 & 17 & 9.18 & 85 & 7.33 \\
\hline 6 & 20 & 10.81 & 120 & 10.35 \\
\hline 7 & 22 & 11.89 & 154 & 13.28 \\
\hline 8 & 15 & 8.10 & 120 & 10.35 \\
\hline 9 & 12 & 6.49 & 108 & 9.31 \\
\hline 10 & 12 & 6.49 & 120 & 10.35 \\
\hline 11 & 4 & 2.16 & 44 & 3.79 \\
\hline 12 & 6 & 3.24 & 72 & 6.21 \\
\hline 13 & 3 & 1.62 & 39 & 3.36 \\
\hline 14 & 2 & 1.08 & 28 & 2.41 \\
\hline 15 & 1 & 0.54 & 15 & 1.29 \\
\hline 16 & - & - & - & - \\
\hline 17 & 3 & 1.62 & 51 & 4.40 \\
\hline 18 & 1 & 0.54 & 18 & 1.55 \\
\hline 19 & 2 & 1.08 & 38 & 3.27 \\
\hline Total & 185 & 100 & 1,159 & 100 \\
\hline
\end{tabular}

Mean size of household

$$
\begin{aligned}
& \mathrm{A}=6.3 \\
& \mathrm{~B}=8.8
\end{aligned}
$$

Median no. of persons$$
\begin{aligned}
& \mathrm{A}=6 \\
& \mathrm{~B}=8
\end{aligned}
$$

\begin{tabular}{|c|c|c|c|c|}
\hline \multirow[b]{2}{*}{ Size } & \multicolumn{2}{|c|}{ Households } & \multicolumn{2}{|c|}{ Persons } \\
\hline & No. & $\%$ & No. & $\%$ \\
\hline 1 & 11 & 10.28 & 12 & 2.03 \\
\hline 2 & 8 & 7.47 & 16 & 2.71 \\
\hline 3 & 10 & 9.34 & 30 & 5.09 \\
\hline 4 & 13 & 12.14 & 52 & 8.82 \\
\hline 5 & 14 & 13.08 & 70 & 11.88 \\
\hline 6 & 21 & 19.62 & 126 & 21.39 \\
\hline 7 & 10 & 9.34 & 70 & 11.88 \\
\hline 8 & 3 & 2.80 & 24 & 4.07 \\
\hline 9 & 3 & 2.80 & 27 & 4.58 \\
\hline 10 & 4 & 3.73 & 40 & 6.79 \\
\hline 11 & 5 & 4.67 & 55 & 9.33 \\
\hline 12 & 1 & 0.93 & 12 & 2.03 \\
\hline 13 & 2 & 1.89 & 26 & 4.41 \\
\hline 14 & 1 & 0.93 & 14 & 2.37 \\
\hline 15 & 1 & 0.93 & 15 & 2.54 \\
\hline Total & 107 & 100 & 589 & 100 \\
\hline \multicolumn{3}{|c|}{ Mean size of household } & \multicolumn{2}{|c|}{ Median no. of persons } \\
\hline \multicolumn{3}{|c|}{$\begin{array}{l}\mathrm{A}=5.5 \\
\mathrm{~B}=7.4\end{array}$} & \multicolumn{2}{|c|}{$\begin{array}{l}\mathrm{A}=5 \\
\mathrm{~B}=6\end{array}$} \\
\hline
\end{tabular}

Table 16.1c Bukovik 
Table 16.1d Kopljare

\begin{tabular}{|c|c|c|c|c|}
\hline \multirow[b]{2}{*}{ Size } & \multicolumn{2}{|c|}{ Households } & \multicolumn{2}{|c|}{ Persons } \\
\hline & No. & $\%$ & No. & $\%$ \\
\hline 1 & 3 & 3.33 & 3 & 0.45 \\
\hline 2 & 3 & 3.33 & 6 & 0.90 \\
\hline 3 & 3 & 3.33 & 9 & 1.35 \\
\hline 4 & 10 & 11.11 & 40 & 6.00 \\
\hline 5 & 10 & 11.11 & 50 & 7.50 \\
\hline 6 & 9 & 10.00 & 54 & 8.10 \\
\hline 7 & 12 & 13.33 & 84 & 12.60 \\
\hline 8 & 13 & 14.44 & 104 & 15.60 \\
\hline 9 & 4 & 4.44 & 36 & 5.40 \\
\hline 10 & 6 & 6.66 & 60 & 9.00 \\
\hline 11 & 3 & 3.33 & 33 & 4.32 \\
\hline 12 & 6 & 6.66 & 72 & 10.80 \\
\hline 13 & 3 & 3.33 & 39 & 5.80 \\
\hline 14 & 2 & 2.22 & 28 & 4.16 \\
\hline 15 & - & - & - & - \\
\hline 16 & 1 & 1.11 & 16 & 2.38 \\
\hline 17 & - & - & - & - \\
\hline 18 & 1 & 1.11 & 18 & 2.67 \\
\hline 19 & - & - & - & - \\
\hline 20 & 1 & 1.11 & 20 & 2.97 \\
\hline Total & 90 & 100 & 672 & 100 \\
\hline
\end{tabular}

Mean size of household Median no. of persons

$$
\begin{aligned}
& \mathrm{A}=7.5 \\
& \mathrm{~B}=9.3
\end{aligned}
$$

$$
\begin{aligned}
& A=7 \\
& B=8
\end{aligned}
$$

\begin{tabular}{|c|c|c|c|c|}
\hline \multirow[b]{2}{*}{ Size } & \multicolumn{2}{|c|}{ Households } & \multicolumn{2}{|c|}{ Persons } \\
\hline & No. & $\%$ & No. & $\%$ \\
\hline 1 & 1 & 0.76 & 1 & 0.09 \\
\hline 2 & 2 & 1.52 & 4 & 0.36 \\
\hline 3 & 5 & 3.81 & 15 & 1.38 \\
\hline 4 & 10 & 7.63 & 40 & 3.69 \\
\hline 5 & 12 & 9.16 & 60 & 5.54 \\
\hline 6 & 15 & 11.45 & 90 & 8.31 \\
\hline 7 & 18 & 13.74 & 126 & 11.64 \\
\hline 8 & 17 & 12.97 & 136 & 12.56 \\
\hline 9 & 9 & 6.87 & 81 & 7.48 \\
\hline 10 & 13 & 9.92 & 130 & 12.01 \\
\hline 11 & 3 & 2.29 & 33 & 3.04 \\
\hline 12 & 13 & 9.92 & 156 & 14.41 \\
\hline 13 & 4 & 3.04 & 52 & 4.86 \\
\hline 14 & 2 & 1.52 & 28 & 2.58 \\
\hline 15 & 2 & 1.52 & 30 & 2.77 \\
\hline 16 & - & - & - & - \\
\hline 17 & - & - & - & - \\
\hline 18 & 2 & 1.52 & 36 & 3.32 \\
\hline 19 & 1 & 0.76 & 19 & 1.75 \\
\hline 20 & - & - & - & - \\
\hline 21 & - & - & - & - \\
\hline 22 & 1 & 0.76 & 22 & 2.03 \\
\hline 23 & 1 & 0.76 & 23 & 2.12 \\
\hline Total & 131 & 100 & 1,082 & 100 \\
\hline \multicolumn{3}{|l|}{ Mean } & \multicolumn{2}{|c|}{ Median no. of persons } \\
\hline \multicolumn{3}{|c|}{$\begin{array}{l}\mathrm{A}=8.3 \\
\mathrm{~B}=10.0\end{array}$} & \multicolumn{2}{|c|}{$\begin{array}{l}\mathrm{A}=8 \\
\mathrm{~B}=9\end{array}$} \\
\hline
\end{tabular}

Table 16.1e Orašac 
Table 16.1f Stojnik

\begin{tabular}{|c|c|c|c|c|}
\hline \multirow[b]{2}{*}{ Size } & \multicolumn{2}{|c|}{ Households } & \multicolumn{2}{|c|}{ Persons } \\
\hline & No. & $\%$ & No. & $\%$ \\
\hline 1 & 14 & 8.38 & 14 & 1.39 \\
\hline 2 & 11 & 6.59 & 22 & 2.18 \\
\hline 3 & 11 & 6.59 & 33 & 3.28 \\
\hline 4 & 20 & 11.98 & 80 & 7.96 \\
\hline 5 & 25 & 14.97 & 125 & 12.43 \\
\hline 6 & 28 & 16.77 & 168 & 16.71 \\
\hline 7 & 15 & 8.98 & 105 & 10.44 \\
\hline 8 & 12 & 7.19 & 96 & 9.55 \\
\hline 9 & 8 & 4.79 & 72 & 7.16 \\
\hline 10 & 5 & 2.99 & 50 & 4.97 \\
\hline 11 & 6 & 3.59 & 66 & 6.56 \\
\hline 12 & 3 & 1.80 & 36 & 3.58 \\
\hline 13 & 2 & 1.20 & 26 & 2.58 \\
\hline 14 & 2 & 1.20 & 28 & 2.78 \\
\hline 15 & - & - & - & - \\
\hline 16 & 2 & 1.20 & 32 & 3.18 \\
\hline 17 & 2 & 1.20 & 34 & 3.83 \\
\hline 18 & 1 & 0.60 & 18 & 1.79 \\
\hline Total & 167 & 100 & 1,005 & 100 \\
\hline
\end{tabular}

Mean size of household Median no. of persons

$$
\begin{aligned}
& \mathrm{A}=6.0 \\
& \mathrm{~B}=8.0
\end{aligned}
$$

$$
\begin{aligned}
& A=6 \\
& B=7
\end{aligned}
$$

\begin{tabular}{|c|c|c|c|c|}
\hline \multirow[b]{2}{*}{ Size } & \multicolumn{2}{|c|}{ Households } & \multicolumn{2}{|c|}{ Persons } \\
\hline & No. & $\%$ & No. & $\%$ \\
\hline 1 & 11 & 4.40 & 11 & 0.68 \\
\hline 2 & 21 & 8.40 & 42 & 2.61 \\
\hline 3 & 13 & 5.20 & 39 & 2.42 \\
\hline 4 & 28 & 11.20 & 112 & 6.96 \\
\hline 5 & 29 & 11.60 & 145 & 9.01 \\
\hline 6 & 32 & 12.80 & 193 & 11.99 \\
\hline 7 & 29 & 11.60 & 203 & 12.61 \\
\hline 8 & 28 & 11.20 & 224 & 13.92 \\
\hline 9 & 18 & 7.20 & 162 & 10.06 \\
\hline 10 & 15 & 6.00 & 148 & 9.19 \\
\hline 11 & 8 & 3.20 & 88 & 5.46 \\
\hline 12 & 6 & 2.40 & 72 & 4.47 \\
\hline 13 & 7 & 2.80 & 91 & 5.73 \\
\hline 14 & 1 & 0.40 & 14 & 0.87 \\
\hline 15 & 2 & 0.80 & 30 & 1.86 \\
\hline 16 & - & - & - & - \\
\hline 17 & 1 & 0.40 & 17 & 1.05 \\
\hline 18 & 1 & 0.40 & 18 & 1.11 \\
\hline Total & 250 & 100 & 1,609 & 100 \\
\hline
\end{tabular}

Table $16.1 \mathrm{~g}$ Topola

Mean size of household

$$
\begin{aligned}
& \mathrm{A}=6.4 \\
& \mathrm{~B}=8.0
\end{aligned}
$$

Median no. of persons

$=8.0$

$\mathrm{A}=6$
$\mathrm{~B}=8$ 
Table $16.1 \mathrm{~h}$ Detailed size of households, all settlements

\begin{tabular}{|c|c|c|c|c|}
\hline \multirow[b]{2}{*}{ Size } & \multicolumn{2}{|c|}{ Households } & \multicolumn{2}{|c|}{ Persons } \\
\hline & No. & $\%$ & No. & $\%$ \\
\hline 1 & 158 & 13.78 & 158 & 2.37 \\
\hline 2 & 83 & 7.24 & 166 & 2.49 \\
\hline 3 & 100 & 8.72 & 300 & 4.51 \\
\hline 4 & 121 & 10.55 & 484 & 7.27 \\
\hline 5 & 127 & 11.08 & 635 & 9.54 \\
\hline 6 & 131 & 11.43 & 786 & 11.81 \\
\hline 7 & 109 & 9.51 & 763 & 11.47 \\
\hline 8 & 89 & 7.76 & 712 & 10.70 \\
\hline 9 & 54 & 4.71 & 486 & 7.30 \\
\hline 10 & 57 & 4.97 & 570 & 8.57 \\
\hline 11 & 29 & 2.53 & 319 & 4.79 \\
\hline 12 & 35 & 3.05 & 420 & 6.31 \\
\hline 13 & 21 & 1.83 & 273 & 4.10 \\
\hline 14 & 10 & 0.87 & 140 & 2.10 \\
\hline 15 & 6 & 0.52 & 90 & 1.35 \\
\hline 16 & 1 & 0.08 & 16 & 0.24 \\
\hline 17 & 6 & 0.52 & 102 & 1.56 \\
\hline 18 & 6 & 0.52 & 108 & 1.62 \\
\hline 19 & 3 & 0.26 & 57 & 0.85 \\
\hline 20 & 1 & 0.08 & 20 & 0.30 \\
\hline 21 & - & - & - & - \\
\hline 22 & 1 & 0.08 & 22 & 0.33 \\
\hline 23 & 1 & 0.08 & 23 & 0.34 \\
\hline Total & 1,149 & 100 & 6,650 & 100 \\
\hline
\end{tabular}

Mean size of household Median no. of persons

$$
\begin{array}{ll}
\mathrm{A}=5.8 & \mathrm{~A}=5 \\
\mathrm{~B}=8.3 & \mathrm{~B}=8
\end{array}
$$

Table 16.2 Household size in all settlements, by percentages in each

\begin{tabular}{|c|c|c|c|c|c|c|c|c|}
\hline \multirow{2}{*}{\multicolumn{2}{|c|}{ Settlement }} & \multicolumn{6}{|c|}{ Size } & \multirow{2}{*}{$\begin{array}{l}\text { No. of } \\
\text { house- } \\
\text { holds }\end{array}$} \\
\hline & & 1 & $2-3$ & $4-5$ & $6-10$ & $11-15$ & $16+$ & \\
\hline Arandjelo & c 1863 & 42.5 & 29.9 & 22.2 & 5.4 & - & - & 221 \\
\hline & 1890 & 8.3 & 27.7 & 34.5 & 26.6 & 2.6 & 0.3 & 383 \\
\hline \multirow{2}{*}{ Banja } & 1863 & 12.8 & 16.2 & 15.1 & 43.8 & 8.6 & 3.2 & 185 \\
\hline & 1890 & 1.1 & 6.5 & 22.9 & 52.7 & 13.7 & 2.7 & 262 \\
\hline \multirow[t]{2}{*}{ Bukovik } & 1863 & 10.3 & 16.8 & 25.2 & 38.3 & 9.3 & - & 107 \\
\hline & 1890 & 3.1 & 16.2 & 33.0 & 43.0 & 2.6 & 2.1 & 191 \\
\hline \multirow{2}{*}{ Kopljare } & 1863 & 3.3 & 6.7 & 22.2 & 48.9 & 15.5 & 3.3 & 90 \\
\hline & 1890 & 3.2 & 14.1 & 23.7 & 48.1 & 7.7 & 3.2 & 156 \\
\hline \multirow[t]{2}{*}{ Orašac } & 1863 & 0.8 & 5.3 & 16.8 & 55.0 & 18.3 & 3.8 & 131 \\
\hline & 1890 & 0.5 & 13.1 & 24.8 & 47.6 & 12.6 & 1.4 & 214 \\
\hline \multirow[t]{2}{*}{ Stojnik } & 1863 & 8.4 & 13.2 & 27.0 & 40.7 & 7.8 & 3.0 & 167 \\
\hline & 1890 & 1.1 & 11.3 & 26.7 & 47.4 & 10.1 & 3.4 & 266 \\
\hline \multirow[t]{2}{*}{ Topola } & 1863 & 4.4 & 13.6 & 22.8 & 48.8 & 9.6 & 0.8 & 250 \\
\hline & 1890 & 2.5 & 17.9 & 27.6 & 45.8 & 5.5 & 0.5 & 435 \\
\hline
\end{tabular}
category, 1863 and 1890, compared ${ }^{a}$

a Based on Population Census of the Kingdom of Serbia 1890 (1892) I: 246, quoted in Halpern (1956) Table 47: 285.

\begin{tabular}{|c|c|c|c|c|}
\hline \multirow[b]{2}{*}{ Size } & \multicolumn{2}{|c|}{ Households } & \multicolumn{2}{|c|}{ Persons } \\
\hline & No. & $\%$ & No. & $\%$ \\
\hline 1 & 151 & 3.8 & 151 & 0.8 \\
\hline 2 & 462 & 11.7 & 924 & 4.8 \\
\hline 3 & 671 & 16.9 & 2,013 & 10.5 \\
\hline 4 & 758 & 19.1 & 3,032 & 15.7 \\
\hline 5 & 753 & 19.0 & 3,765 & 19.5 \\
\hline 6 & 468 & 11.8 & 2,808 & 14.6 \\
\hline 7 & 299 & 7.5 & 2,093 & 10.9 \\
\hline 8 & 181 & 4.6 & 1,448 & 7.5 \\
\hline 9 & 85 & 2.1 & 765 & 4.0 \\
\hline 10 & 75 & 1.9 & 750 & 3.9 \\
\hline Over 10 & 62 & 1.6 & 1,523 & 7.9 \\
\hline Total & 3,965 & 100 & 19,272 & 100 \\
\hline
\end{tabular}

Table 16.3 Republic of Dubrovnik, 1673-4 ${ }^{a}$

Mean household size $=5.0$. ${ }^{a}$ Sundrica (1959).

Mean size of household

Median no. of persons
A
$\mathrm{A}=4$
$\mathrm{~B}=5$ 
Tables 16.4a-f Children by kin relationship, sex, and as a proportion of the population, 1863 , by settlements

Table $16.4 a$ Arandjelovac

\begin{tabular}{|c|c|c|c|c|}
\hline \multirow[b]{2}{*}{ Kin relationship } & \multicolumn{4}{|c|}{ Children $^{a}$} \\
\hline & Male & Female & Total & $\%$ \\
\hline Child of head & 97 & 92 & 189 & 91.3 \\
\hline Grandchild of head & 3 & 0 & 3 & 1.44 \\
\hline Child of other household member ${ }^{b}$ & 7 & 8 & 15 & 7.24 \\
\hline Total & 107 & 100 & 207 & 100 \\
\hline $\begin{array}{ll}\text { Children } \\
\text { Total population }\end{array}$ & & & & \\
\hline
\end{tabular}

${ }^{a}$ Children are defined here as eighteen years or younger and unmarried.

$b$ Primarily children of brother of household head.

Table $16.4 b \quad$ Banja

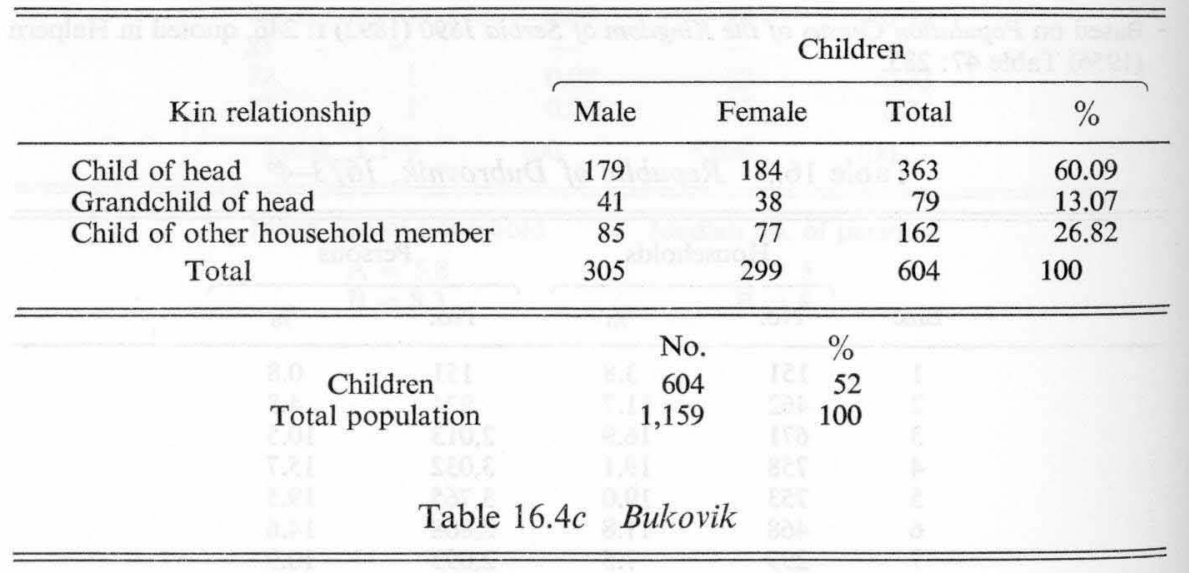

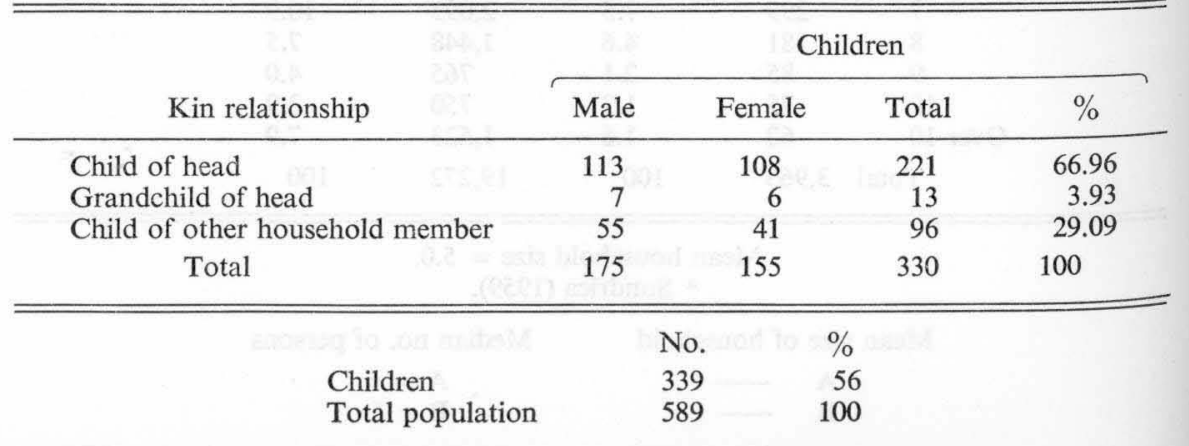

Table $16.4 d$ Kopljare

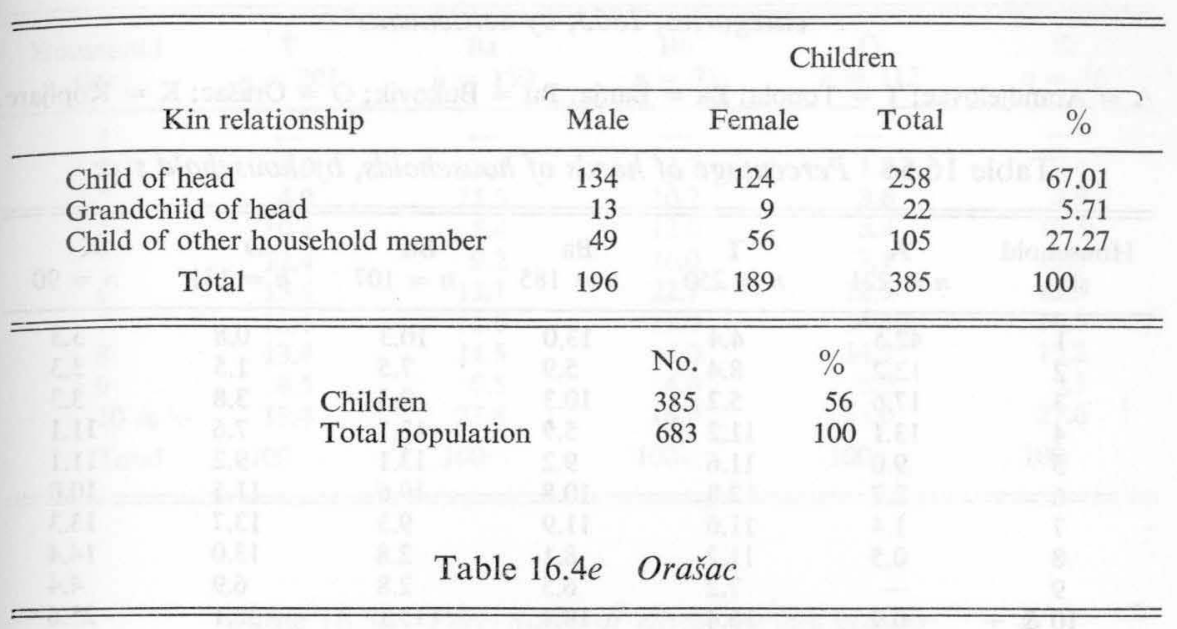

\begin{tabular}{lrrrr}
\hline \hline \multirow{2}{*}{ Kin relationship } & \multicolumn{5}{c}{ Children } \\
\cline { 2 - 5 } & Male & Female & Total & $\%$ \\
\hline Child of head & 196 & 199 & 395 & 63.40 \\
Grandchild of head & 56 & 39 & 95 & 15.24 \\
Child of other household member & 63 & 70 & 133 & 21.34 \\
Total & 315 & 308 & 623 & 100 \\
\hline \hline & & No. & $\%$ & \\
& Children & 623 & 58 & \\
& Total population & 1,082 & 100 &
\end{tabular}

Table $16.4 f$ Topola

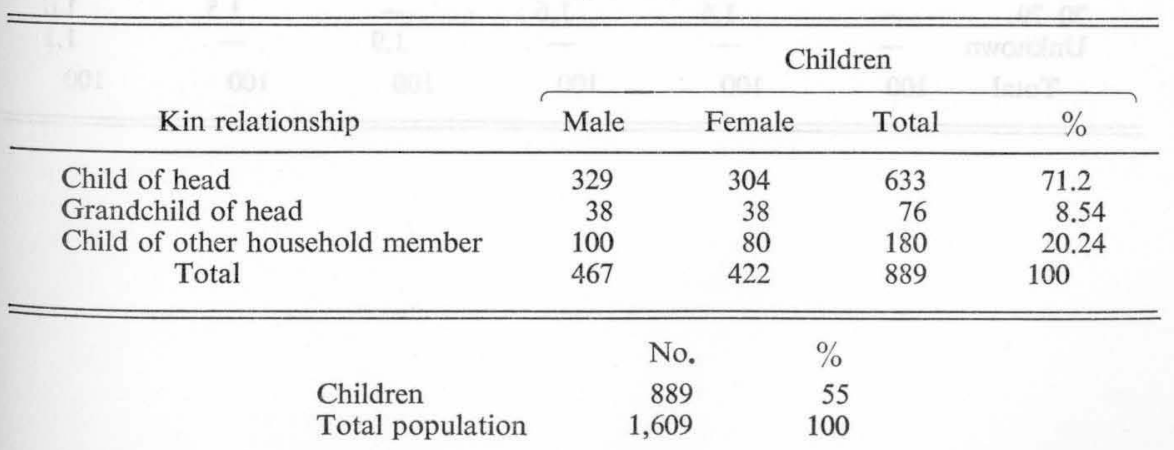


Tables 16.5a-p Structure of households, by selected kin categories, 1863, by settlements ${ }^{a}$

$\mathrm{A}=$ Arandjelovac $; \mathrm{T}=$ Topola $; \mathrm{Ba}=$ Banja $; \mathrm{Bu}=$ Bukovik $; \mathrm{O}=$ Orašac $; \mathrm{K}=$ Kopljare

Table 16.5a Percentage of heads of households, by household size

\begin{tabular}{ccccccc}
\hline $\begin{array}{c}\text { Household } \\
\text { size }\end{array}$ & $\begin{array}{c}\mathrm{A} \\
n=221\end{array}$ & $\begin{array}{c}\mathrm{T} \\
n=250\end{array}$ & $\begin{array}{c}\mathrm{Ba} \\
n=185\end{array}$ & $\begin{array}{c}\mathrm{Bu} \\
n=107\end{array}$ & $\begin{array}{c}\mathrm{O} \\
n=131\end{array}$ & $\begin{array}{c}\mathrm{K} \\
n=90\end{array}$ \\
\hline 1 & 42.5 & 4.4 & 13.0 & 10.3 & 0.8 & 3.3 \\
2 & 12.2 & 8.4 & 5.9 & 7.5 & 1.5 & 3.3 \\
3 & 17.6 & 5.2 & 10.3 & 9.3 & 3.8 & 3.3 \\
4 & 13.1 & 11.2 & 5.9 & 12.1 & 7.6 & 11.1 \\
5 & 9.0 & 11.6 & 9.2 & 13.1 & 9.2 & 11.1 \\
6 & 2.7 & 12.8 & 10.8 & 19.6 & 11.5 & 10.0 \\
7 & 1.4 & 11.6 & 11.9 & 9.3 & 13.7 & 13.3 \\
8 & 0.5 & 11.2 & 8.1 & 2.8 & 13.0 & 14.4 \\
9 & - & 7.2 & 6.5 & 2.8 & 6.9 & 4.4 \\
10 \& + & 0.9 & 16.4 & 18.4 & 13.1 & 32.1 & 25.6 \\
Total & 100 & 100 & 100 & 100 & 100 & 100 \\
\hline \hline
\end{tabular}

${ }^{a}$ This series is arranged in the order of kin categories used in the 1863 Serbian Census.

Table 16.5b Percentage of heads of households, by age groups

\begin{tabular}{lcccccc}
\hline \hline Age & $\begin{array}{c}\mathrm{A} \\
n=221\end{array}$ & $\begin{array}{c}\mathrm{T} \\
n=250\end{array}$ & $\begin{array}{c}\mathrm{Ba} \\
n=185\end{array}$ & $\begin{array}{c}\mathrm{Bu} \\
n=107\end{array}$ & $\begin{array}{c}\mathrm{O} \\
n=131\end{array}$ & $\begin{array}{c}\mathrm{K} \\
n=90\end{array}$ \\
\hline $10-19$ & 12.3 & 4.4 & 8.1 & 12.1 & 3.8 & 8.9 \\
$20-29$ & 36.1 & 22.4 & 25.9 & 29.9 & 13.7 & 24.4 \\
$30-39$ & 26.5 & 30.4 & 23.8 & 38.3 & 24.4 & 25.6 \\
$40-49$ & 18.3 & 23.2 & 20.5 & 12.1 & 28.2 & 27.8 \\
$50-59$ & 5.5 & 14.0 & 13.0 & 2.8 & 19.1 & 7.8 \\
$60-69$ & 1.4 & 4.0 & 7.0 & 2.8 & 9.2 & 4.4 \\
$70-79$ & - & 1.6 & 1.6 & - & 1.5 & 1.0 \\
Unknown & - & - & - & 1.9 & - & 1.1 \\
Total & 100 & 100 & 100 & 100 & 100 & 100 \\
\hline \hline
\end{tabular}

Table 16.5c Percentage of wives, by household size

\begin{tabular}{cccccc}
\hline \hline $\begin{array}{c}\text { Household } \\
\text { size }\end{array}$ & $\begin{array}{c}\mathrm{T} \\
n=201\end{array}$ & $\begin{array}{c}\mathrm{Ba} \\
n=130\end{array}$ & $\begin{array}{c}\mathrm{Bu} \\
n=75\end{array}$ & $\begin{array}{c}\mathrm{O} \\
n=112\end{array}$ & $\begin{array}{c}\mathrm{K} \\
n=76\end{array}$ \\
\hline 1 & $\overline{-}$ & $\overline{2.3}$ & $\overline{2.7}$ & $\overline{1.8}$ & $\overline{2}$ \\
2 & 5.0 & 11.5 & 10.7 & 3.6 & 3.9 \\
3 & 4.0 & 5.4 & 12.0 & 5.4 & 10.5 \\
4 & 10.4 & 9.2 & 16.0 & 7.1 & 11.8 \\
5 & 12.4 & 13.1 & 22.7 & 12.5 & 10.5 \\
6 & 15.4 & 14.6 & 12.0 & 14.3 & 14.5 \\
7 & 12.4 & 11.5 & 4.0 & 14.3 & 13.2 \\
8 & 13.4 & 8.5 & 4.0 & 8.0 & 5.3 \\
9 & 8.5 & 16.8 & 16.0 & 33.0 & 27.6 \\
$10 \&+$ & 18.4 & 100 & 100 & 100 & 100 \\
Total & 100 & & & & \\
\hline \hline
\end{tabular}

Table 16.5d Percentage of wives, by age groups

\begin{tabular}{cccccc}
\hline \hline Age & $\begin{array}{c}\mathrm{T} \\
n=201\end{array}$ & $\begin{array}{c}\mathrm{Ba} \\
n=130\end{array}$ & $\begin{array}{c}\mathrm{Bu} \\
n=75\end{array}$ & $\begin{array}{c}\mathrm{O} \\
n=112\end{array}$ & $\begin{array}{c}\mathrm{K} \\
n=76\end{array}$ \\
\hline $0-9$ & $\overline{-}$ & $\overline{0.8}$ & $\overline{5.3}$ & - & $\overline{-}$ \\
$10-19$ & 2.0 & 37.7 & 44.0 & 25.9 & 40.8 \\
$20-29$ & 31.8 & 32.3 & 37.3 & 35.7 & 34.2 \\
$30-39$ & 34.3 & 19.2 & 9.3 & 20.5 & 15.8 \\
$40-49$ & 19.4 & 9.2 & 2.7 & 17.9 & 6.6 \\
$50-59$ & 9.5 & - & - & - & - \\
$60-69$ & 2.5 & 0.8 & 1.3 & - & 100 \\
$70-79$ & 0.5 & 100 & 100 & 100 & 100 \\
Total & 100 & & & & \\
\hline \hline
\end{tabular}


Table 16.5e Percentage of sons, by household size

\begin{tabular}{cccccc}
\hline $\begin{array}{c}\text { Household } \\
\text { size }\end{array}$ & $\begin{array}{c}\mathrm{T} \\
n=390\end{array}$ & $\begin{array}{c}\mathrm{Ba} \\
n=227\end{array}$ & $\begin{array}{c}\mathrm{Bu} \\
n=119\end{array}$ & $\begin{array}{c}\mathrm{O} \\
n=257\end{array}$ & $\begin{array}{c}\mathrm{K} \\
n=153\end{array}$ \\
\hline 1 & $\overline{1}$ & $\overline{-}$ & - & - & - \\
2 & 0.5 & 1.3 & $\overline{-}$ & $\overline{-}$ & 0.7 \\
3 & 2.1 & 3.1 & 3.4 & 0.4 & $\overline{6}$ \\
4 & 6.9 & 3.1 & 8.4 & 2.7 & 7.2 \\
5 & 10.3 & 6.2 & 8.4 & 6.2 & 12.4 \\
6 & 13.8 & 11.9 & 26.1 & 10.1 & 13.1 \\
7 & 13.6 & 16.7 & 14.3 & 15.6 & 4.3 \\
8 & 13.3 & 11.0 & 7.6 & 19.5 & 5.8 \\
9 & 12.6 & 6.6 & 5.9 & 59.7 & 39.2 \\
$10 \&+$ & 26.9 & 40.1 & 26.1 & 39.7 & 100 \\
Total & 100 & 100 & 100 & 100 & \\
\hline \hline
\end{tabular}

Table 16.5f Percentage of sons, by age groups

\begin{tabular}{cccccc}
\hline \hline & $\mathrm{T}$ & $\mathrm{Ba}$ & $\mathrm{Bu}$ & $\mathrm{O}$ & $\mathrm{K}$ \\
Age & $n=390$ & $n=227$ & $n=119$ & $n=257$ & $n=153$ \\
\hline $0-9$ & 52.1 & 50.2 & 61.3 & 46.3 & 51.6 \\
$10-19$ & 33.8 & 30.4 & 34.5 & 30.7 & 36.6 \\
$20-29$ & 11.8 & 13.2 & 4.2 & 17.5 & 10.5 \\
$30-39$ & 2.3 & 5.7 & - & 4.7 & 1.3 \\
$40-49$ & - & 0.4 & - & 0.8 & - \\
$50-59$ & - & - & - & - & 100 \\
Total & 100 & 100 & 100 & 100 & 100 \\
\hline \hline
\end{tabular}

Table 16.5g Percentage of daughters, by household size

\begin{tabular}{cccccc}
\hline $\begin{array}{c}\text { Household } \\
\text { size }\end{array}$ & $\begin{array}{c}\mathrm{T} \\
n=312\end{array}$ & $\begin{array}{c}\mathrm{Ba} \\
n=195\end{array}$ & $\begin{array}{c}\mathrm{Bu} \\
n=109\end{array}$ & $\begin{array}{c}\mathrm{O} \\
n=203\end{array}$ & $\begin{array}{c}\mathrm{K} \\
n=131\end{array}$ \\
\hline 1 & - & $\overline{1.0}$ & $\overline{1.8}$ & - & - \\
2 & 0.6 & 3.6 & 2.8 & $\overline{2}$ & - \\
3 & 1.0 & 5.1 & 6.3 & 2.5 & 2.3 \\
4 & 8.0 & 10.8 & 19.3 & 4.9 & 6.6 \\
5 & 10.6 & 10.8 & 22.0 & 12.3 & 9.9 \\
6 & 14.1 & 16.9 & 22.9 & 15.8 & 14.5 \\
7 & 12.8 & 10.8 & 2.8 & 17.7 & 14.5 \\
8 & 15.7 & 8.7 & 5.5 & 7.9 & 9.2 \\
9 & 12.8 & 32.3 & 16.5 & 36.9 & 38.2 \\
$10 \&+$ & 24.4 & 100 & 100 & 100 & 100 \\
Total & 100 & & & & \\
\hline \hline
\end{tabular}

Table 16.5h Percentage of daughters, by age groups

\begin{tabular}{cccccc}
\hline \hline Age & $\begin{array}{c}\mathrm{T} \\
n=312\end{array}$ & $\begin{array}{c}\mathrm{Ba} \\
n=195\end{array}$ & $\begin{array}{c}\mathrm{Bu} \\
n=109\end{array}$ & $\begin{array}{c}\mathrm{O} \\
n=203\end{array}$ & $\begin{array}{c}\mathrm{K} \\
n=131\end{array}$ \\
\hline $0-9$ & 58.7 & 57.9 & 71.6 & 62.6 & 64.9 \\
$10-19$ & 40.1 & 37.9 & 28.4 & 36.0 & 33.6 \\
$20-29$ & 1.3 & 3.6 & - & 1.5 & 1.5 \\
$30-39$ & - & 0.5 & - & - & - \\
$40-49$ & - & - & - & - & 100 \\
Total & 100 & 100 & 100 & 100 & 100 \\
\hline \hline
\end{tabular}


Table 16.5i Percentage of brothers, by household size

\begin{tabular}{cccccc}
\hline \hline $\begin{array}{c}\text { Household } \\
\text { Size }\end{array}$ & $\begin{array}{c}\mathrm{T} \\
n=91\end{array}$ & $\begin{array}{c}\mathrm{Ba} \\
n=92\end{array}$ & $\begin{array}{c}\mathrm{Bu} \\
n=41\end{array}$ & $\begin{array}{c}\mathrm{O} \\
n=68\end{array}$ & $\begin{array}{c}\mathrm{K} \\
n=50\end{array}$ \\
\hline 1 & $\overline{4.4}$ & $\overline{1.1}$ & $\overline{4.9}$ & - & - \\
2 & 4.4 & 4.3 & 4.9 & $\overline{-}$ & - \\
3 & 2.2 & 2.2 & 17.1 & 7.4 & - \\
4 & 6.6 & 4.3 & 7.3 & 4.4 & 4.0 \\
5 & 11.0 & 13.0 & 17.1 & 5.9 & 2.0 \\
6 & 18.7 & 17.4 & 2.4 & 7.4 & 14.0 \\
7 & 16.5 & 8.7 & 2.4 & 5.9 & 24.0 \\
8 & 4.4 & 17.4 & 7.3 & 8.8 & - \\
9 & 31.9 & 31.5 & 36.6 & 58.8 & 48.0 \\
$10 \&+$ & 100 & 100 & 100 & 100 & 100 \\
Total & 100 & & & & \\
\hline \hline
\end{tabular}

Tabel 16.5j Percentage of brothers, by age groups

\begin{tabular}{cccccc}
\hline \hline Age & $\begin{array}{c}\mathrm{T} \\
n=91\end{array}$ & $\begin{array}{c}\mathrm{Ba} \\
n=92\end{array}$ & $\begin{array}{c}\mathrm{Bu} \\
n=41\end{array}$ & $\begin{array}{c}\mathrm{O} \\
n=68\end{array}$ & $\begin{array}{c}\mathrm{K} \\
n=50\end{array}$ \\
\hline $0-9$ & 7.7 & 12.0 & 29.3 & 8.8 & 24.0 \\
$10-19$ & 38.5 & 41.3 & 24.4 & 26.5 & 32.0 \\
$20-29$ & 36.3 & 29.3 & 34.1 & 33.8 & 26.0 \\
$30-39$ & 9.9 & 12.0 & 7.3 & 26.5 & 18.0 \\
$40-49$ & 5.5 & 4.3 & 4.9 & 2.9 & - \\
$50-59$ & 1.1 & 1.1 & - & - & - \\
$60-69$ & 1.1 & - & - & - & - \\
$70-79$ & - & - & - & 1.5 & 100 \\
Total & 100 & 100 & 100 & 100 & 100 \\
\hline \hline
\end{tabular}

Table $16.5 k$ Percentage of grandsons, by household size

\begin{tabular}{cccccc}
\hline \hline $\begin{array}{c}\text { Household } \\
\text { size }\end{array}$ & $\begin{array}{c}\mathrm{T} \\
n=38\end{array}$ & $\begin{array}{c}\mathrm{Ba} \\
n=41\end{array}$ & $\begin{array}{c}\mathrm{Bu} \\
n=9\end{array}$ & $\begin{array}{c}\mathrm{O} \\
n=39\end{array}$ & $\begin{array}{c}\mathrm{K} \\
n=15\end{array}$ \\
\hline 1 & - & - & - & - & - \\
2 & 2.6 & - & - & - & - \\
3 & - & - & - & - & - \\
4 & - & 2.4 & - & - & - \\
5 & - & 2.4 & - & - & - \\
6 & $\overline{-}$ & 7.3 & 22.2 & - & - \\
7 & 15.3 & 2.4 & -1.7 & - & 6.7 \\
8 & 13.2 & 4.9 & 11.1 & 12.8 & 93.3 \\
9 & 53.7 & 55.6 & 79.5 & 100 \\
$10 \&+$ & 100 & 100 & 100 & 100 & \\
Total & 100 & & &
\end{tabular}

Table $16.5 \mathrm{l}$ Percentage of grandsons, by age groups

\begin{tabular}{cccccc}
\hline \hline & $\mathrm{T}$ & $\mathrm{Ba}$ & $\mathrm{Bu}$ & $\mathrm{O}$ & $\mathrm{K}$ \\
Age & $n=38$ & $n=41$ & $n=9$ & $n=56$ & $n=15$ \\
\hline $0-9$ & 92.1 & 85.4 & 77.8 & 85.7 & 66.7 \\
$10-19$ & 7.9 & 14.6 & 11.1 & 14.3 & 20.0 \\
$20-29$ & - & - & 11.1 & - & 13.3 \\
$30-39$ & - & - & - & - & 100 \\
Total & 100 & 100 & 100 & 100 \\
\hline \hline
\end{tabular}


Table $16.5 m$ Percentage of nephews (brothers' sons), by household size

\begin{tabular}{|c|c|c|c|c|c|}
\hline $\begin{array}{l}\text { Household } \\
\text { size }\end{array}$ & $\begin{array}{c}\mathrm{T} \\
n=62\end{array}$ & $\begin{array}{c}\mathrm{Ba} \\
n=41\end{array}$ & $\begin{array}{c}\mathrm{Bu} \\
n=34\end{array}$ & $\begin{array}{c}\mathrm{O} \\
n=43\end{array}$ & $\stackrel{\mathrm{K}}{n=25}$ \\
\hline 1 & - & - & - & - & - \\
\hline 2 & - & - & - & - & - \\
\hline 3 & - & - & - & - & - \\
\hline 4 & - & - & 2.9 & - & - \\
\hline 5 & 3.2 & - & 5.9 & - & - \\
\hline 6 & 4.8 & 4.9 & 11.8 & - & - \\
\hline 7 & 4.8 & 9.8 & 8.8 & 2.3 & 4.0 \\
\hline 8 & 14.5 & - & 5.9 & 2.3 & 4.0 \\
\hline 9 & 9.7 & 2.4 & - & 2.3 & 8.0 \\
\hline $10 \&+$ & 62.9 & 82.9 & 64.7 & 93.0 & 84.0 \\
\hline Total & 100 & 100 & 100 & 100 & 100 \\
\hline
\end{tabular}

Table $16.5 n$ Percentage of nephews, by age groups

\begin{tabular}{cccccc}
\hline \hline Age & T & $\begin{array}{c}\mathrm{Ba} \\
n=62\end{array}$ & $n=41$ & $\begin{array}{c}\mathrm{Bu} \\
n=34\end{array}$ & $\begin{array}{c}\mathrm{O}=43 \\
\mathbf{K}\end{array}$ \\
\hline $0-9$ & 62.7 & 68.3 & 67.6 & 83.7 & 64.0 \\
$10-19$ & 35.5 & 26.8 & 23.5 & 7.0 & 20.0 \\
$20-29$ & 1.6 & 4.9 & 8.8 & 9.3 & 4.0 \\
$30-39$ & - & - & - & - & 8.0 \\
$40-49$ & - & - & - & - & 4.0 \\
Total & 100 & 100 & 100 & 100 & 100 \\
\hline \hline
\end{tabular}

Table 16.5o Percentage of daughters-in-law, by household size

\begin{tabular}{cccccc}
\hline $\begin{array}{c}\text { Household } \\
\text { size }\end{array}$ & $\begin{array}{c}\mathrm{T} \\
n=50\end{array}$ & $\begin{array}{c}\mathrm{Ba} \\
n=40\end{array}$ & $\begin{array}{c}\mathrm{Bu} \\
n=6\end{array}$ & $\begin{array}{c}\mathrm{O} \\
n=50\end{array}$ & $\begin{array}{c}\mathrm{K} \\
n=14\end{array}$ \\
\hline 1 & - & - & - & - & - \\
2 & - & - & - & - & - \\
3 & $\overline{-}$ & - & - & - & - \\
4 & 2.0 & - & - & 2.0 & - \\
5 & 6.0 & 2.5 & - & 2.0 & - \\
6 & 6.0 & 5.0 & 16.7 & 2.0 & - \\
7 & 8.0 & 2.5 & - & 12.0 & 14.3 \\
8 & 14.0 & 12.5 & 16.7 & 10.0 & 21.4 \\
9 & 12.0 & 5.0 & 33.3 & 8.0 & 64.3 \\
$10 \&+$ & 52.0 & 72.5 & 33.3 & 64.0 & 100 \\
Total & 100 & 100 & 100 & 100 & \\
\hline \hline
\end{tabular}

Table 16.5p Percentage of daughters-in-law, by age groups

\begin{tabular}{cccccc}
\hline \hline Age & $\begin{array}{c}\mathrm{T} \\
n=50\end{array}$ & $\begin{array}{c}\mathrm{Ba} \\
n=40\end{array}$ & $\begin{array}{c}\mathrm{Bu} \\
n=6\end{array}$ & $\begin{array}{c}\mathrm{O} \\
n=50\end{array}$ & $\begin{array}{c}\mathrm{K} \\
n=14\end{array}$ \\
\hline $0-9$ & - & $\overline{2.5}$ & $\overline{16.7}$ & $\overline{4.0}$ & $\overline{7.1}$ \\
$10-19$ & 10.0 & 77.5 & 83.3 & 80.0 & 71.4 \\
$20-29$ & 82.0 & 17.5 & - & 10.0 & 21.4 \\
$30-39$ & 8.0 & -5.5 & - & 4.0 & - \\
$40-49$ & - & - & - & 2.0 & - \\
$50-59$ & - & 100 & 100 & 100 & 100 \\
Total & 100 & &
\end{tabular}

